DOI: $10.14746 /$ por.2018.1.16

\title{
OPOWIEŚCIOWY WZÓR PRZEZNACZENIA BOHATERÓW ${ }^{1}$
}

\author{
Mariana Čechovín \\ (Univerzita Konštantína Filozofa, Nitra)
}

Słowa kluczowe: baśniowy typ "protegowany losu”, algorytmy narracyjne, międzykulturowe paralele

Key words: folktale type "protected by fate", narrative algorithms, transcultural parallels

\begin{abstract}
Abstrakt: Mariana Čechová, OPOWIEŚCIOWY WZÓR PRZEZNACZENIA BOHATERÓW. „PORÓWNANIA" 1 (22), 2018. T. XXII, S. 289-301. ISSN 1733-165X. Wynikiem analizy baśniowych typów 461 i 930 („protegowany losu“) jest określenie ich tematyczno-motywicznych przejawów w kontekście europejskich i azjatyckich tradycji literackich, które mają międzykulturową „ważność". Niezmiennym semantemem wszystkich wymienionych mitycznych, baśniowych czy legendowych opowieści jest nieudana próba zabicia przez wysoko postawionego, posiadającego władzę mężczyznę tego, kto według przepowiedni czy wróżby ma stać się jego następcą. Integralną częścią tego odwiecznego, starego motywu są - w wielu przypadkach - także znane motywy biblijne, jak na przykład prześladowanie niemowlęcia, znaki z nieba czy spełnienie przepowiedni.
\end{abstract}

\begin{abstract}
Mariana Čechová, THE STORY MODEL OF THE HERO OF PREDESTINATION. "PORÓWNANIA" 1 (22), 2018. Vol. XXII, P. 289-301. ISSN 1733-165X. The result of the analysis of folk types 461 and 930 ('protected by fate') is identification of their thematic-motivic intersections in the comparative framework of European and Asian literary tradition. At the same time, these intersections are valid inter-culturally. The research shows that an invariant semanteme of all studied myths, folk tales and legends is an unsuccessful attempt of a man of high social standing and power to kill his successor chosen by fate. The discussed ancient story motif also contains the famous Biblical motifs, such as the persecution of a child, heavenly omens and the fulfilment of prophecies.
\end{abstract}

1 Badania powstały w ramach projektu VEGA 1/0426/17 Ikonizacja cierpienia i jego znaczenia w literackim, artystycznym i kulturowym obrazie I (intersemiotyczna, interdyscyplinarna i międzykulturowa rekognicja).

2 E-mail: mcechova@ukf.sk 
W poniższym artykule pragnę skupić się na dwóch pokrewnych typach baśniowych o "protegowanych losu”, które zgodnie z międzynarodową klasyfikacją typów baśni (dalej jako ATU) zarejestrowane są osobno jako: ATU 930 Wróżba i ATU 461 Trzy włosy $z$ czarciej brody. Te tematyczne algorytmy ludowych opowieści mają swoje źródło w znacznie starszych literackich materiałach.

\section{Typ baśniowy Wróżba}

Na początku należałoby przypomnieć tematyczny schemat baśniowego typu ATU 930 Wróżba (Ubogi chłopiec i bogacz):

I. Wróżba: a) chłopiec dowiaduje się z przepowiedni, że zostanie zięciem króla.

II. Sprzedanie i porzucenie: a) król wykupuje od rodziców biednego chłopca, o którym dowiaduje się że - według wróżby - zostanie jego następcą; b) spuszcza beczkę z uwięzionym w niej chłopcem do rzeki albo zostawia chłopca w lesie; c) chłopca ratuje i przyjmuje do siebie młynarz, pasterz, myśliwy lub handlarz.

III. Uriaszowy list: a) król znajduje chłopca i posyła go do królowej z listem, w którym żąda, by ta zabiła chłopca; b) po drodze zatrzymują go rozbójnicy, ci podmieniają list na inny, w którym pada żądanie, żeby chłopiec otrzymał za żonę królewnę.

Przy oznaczaniu ostatniej sekwencji tego baśniowego typu („Uriaszowy list”) autorzy ATU najprawdopodobniej inspirowali się historią biblijną o Uriaszu Hetycie (2 Sm 10-11), którego król Dawid chciał zabić, aby móc ożenić się z jego żoną. Wysłał dowódcy wojska list z żądaniem, żeby ten ustawił Uriasza na pierwszej linii walk. Tak się też stało. Uriasz zginął w walce, a król Dawid poślubił jego żonę.

Biblijną opowieść o Uriaszu z baśniowym typem Wróżba łączy zatem motyw podstępnego listu: wysoko postawiony mężczyzna wysyła z wiadomością podporządkowanego sobie rywala, który ma się znaleźć na miejscu własnej śmierci.

Czeski folklorysta Karel Horálek w związku z kluczowym motywem „listu śmierci” (ewentualnie „wyroku śmierci”), który sam skazany dostarcza adresatowi, nawiązuje do średniowiecznych europejskich legend. W nich sekwencja „Uriaszowego listu" jest wykorzystywana jako niezależny materiał opowieści (Horálek 130). Horálek zwraca uwagę na pracę francuskiego badacza Emmanuela Cosquina La Légende du page desainte Elisabeth de Portugalet les nouveaux documents orientaux (1912), który zwrócił uwagę na analogię między opowieścią o "protegowanym losu” a średniowieczną legendą o św. Elżbiecie portugalskiej. Mowa w niej jest o tym, że bogobojna królowa przy wyznaczaniu jałmużny poprosiła o pomoc pewnego pazia. Inny młody dworzanin, zazdroszcząc swojemu koledze przychylności królowej, wmówił królowi, że jego żona nawiązała niedozwolone kontakty z paziem. Król postanowił 
ukarać domniemanego rywala - zdecydował, że pozbawi pazia życia poprzez wysłanie go z listem do huty, gdzie hutnicy wrzucą go do pieca. Młodzieniec jednak po drodze zatrzymuje się w kościele. Tymczasem król wysyła do huty kolejnego posłańca, którego spotyka los, jaki czekał pazia (Horálek 130). Stąd też Václav Tille proponuje, by tę sekwencję nazywać „wiadomością do hut” (Tille 1919: 370).

Jak łatwo dostrzec, różnica między biblijną historią a średniowieczną legendą leży $\mathrm{w}$ tym, że $\mathrm{w}$ tej pierwszej osoba niosąca list umiera, a $\mathrm{w}$ drugiej zostaje uratowana. Podobne do drugiej opowieści zakończenie ma czeska bajka Protegowany losu (wersja baśniowego typu ATU 930 Wróżba), w której król usiłuje pogodzić się z losem młodzieńca i przyjmuje go jako swojego zięcia.

Poszczególnym folklorystycznym tekstom typu „protegowany losu” poświęcona jest monografia fińskiego badacza Antti Aarnego Der reiche Mann und sein Schwiegersohn (Bogacz i jego zięć) (1916). Przy jej koncypowaniu Aarne jako punkt wyjścia obrał prawdopodobnie dane, które przedstawili Johannes Bolte i Jiří Polívka w komentarzu do baśni braci Grimm Der Teufel mit den drei goldenen Haaren (Czarcie trzy złote włosy) ${ }^{3}$, zestawił je także z pracą Josepha Schicka Corpus Hamleticum (1912), którego badania skupiały się wokół podstawowych treści i podstawowego źródła Hamleta Shakespeare'a - irlandzkiej legendy o Amlecie ${ }^{4}$. Legenda została zapisana w dziele Gesta Danorum autorstwa średniowiecznego duńskiego kronikarza Saxa Grammatica (XII wiek)

Następnie Aarne, w zgodności z wytycznymi Cosquina i Josefa Schicka, wysunął hipotezę, że typ "protegowany losu” ma swoje korzenie w chińskiej i indyjskiej literaturze. Uważa, że najstarszymi znanymi tekstami, które odpowiadają temu typowi, są buddyjska narracja z Chin (III wiek), której bohaterem jest sam Boddhisattva (Tripitaka $\left.{ }^{6}\right)$, i buddyjska narracja z Indii (V wiek), w której z kolei protegowanym

3 Zob. Bolte, Polívka 276. Badacze ci ogółem zebrali i skomentowali około stu tekstów o protegowanym losu (zwłaszcza warianty baśni braci Grimm, inne teksty niemieckie, flamandzkie, duńskie, szwedzkie, norweskie, fińskie, islandzkie, hiszpańskie, portugalskie, serbsko-chorwackie, słowackie, czeskie, polskie, rosyjskie, tureckie itd.).

4 Historia Amletha pojawiła się także na obszarze norwesko-islandzkim - w zbiorze staronorweskich mitologicznych pieśni Edda autorstwa Snorriego Sturlusuna, do którego to zbioru zostały dołączone strofy islandzkiego skalda Snæbjörna (około 1000 roku, czyli na dwa stulecia przed Grammatica Chronicle). O istnieniu baśni typu amletowskiego na Islandii może świadczyć Opowieść o Brjamie zapisana w $1707 \mathrm{roku}$, oparta na podaniach Saxa, niezależna ludowa opowieść o biednym chłopcu, który postanawia zemścić się na królu za zamordowanie jego ojca i braci i sam zostaje królem (Kadečková 4-23).

5 Według Schicka Shakespeare nie wychodził bezpośrednio od tego tekstu, ale z powtórnego opowiedzenia przedstawionej legendy, którą w XVI wieku zapisał francuski autor Francois de Beleforest w dziele Histoires tragiques (1567). Opowieść Grammatica o Amlecie łączy z typem „protegowany losu" podwójny motyw podstępnego listu. Bohater tej opowieści udaje obłąkanego, przy czym właśnie w pozornie irracjonalnych odpowiedziach przejawia się jego inteligencja. Za pierwszym razem Amleth wymienia list, w którym na śmierć wysyła go jego stryj, za drugim razem list wymienia królowa, która pragnie poślubić Amletha.

6 Dosłownie "trójkosz”, nazwa buddyjskich tekstów kanonicznych. 
jest Ghósaka ${ }^{7}$ W obu tekstach mowa o porzuconym niemowlęciu, któremu prorokowano, że zostanie spadkobiercą bogacza. Bogacz zajmie się opuszczonym dzieckiem, ale w chwili, gdy urodzi mu się własny syn, będzie próbował zabić podrzutka. Wszystkie podstępy pójdą jednak na marne. Porzucone niemowlę albo wykarmią owce (Boddhisattva), albo uratuje byk (Ghósaka). Gdy bogacz zostawi dziecko na drodze, żeby zostało zadeptane przez dzikie zwierzęta, te uratują „protegowanego losu". A gdy wreszcie bogacz porzuci malca na pastwę losu w gaju umarłych, wykarmi go koza (Boddhisattva). W końcu bogacz wrzuci niemowlę w gęstwiny, ale ono nawet stamtąd wydostanie się bez uszczerbku na zdrowiu i wróci do bogacza. Kolejną intrygą wobec chłopca będzie przekazanie wiadomości do hut: bogacz wyśle chłopca do swojego gońca z listem, w którym roztacza się widmo śmierci, ale chłopiec zostanie uratowany, ponieważ dziewczyna, z którą potem weźmie ślub, wymieni list. Na koniec zamiast chłopca śmierć poniesie syn bogacza. Tym samym przepowiednia, która padła na początku opowieści, w końcu się wypełni (Tille 1918: 373-375).

Tille odsyła do jeszcze starszego tekstu o podobnej treści. Rzymski historyk Pompejusz Trogus w pierwszej dekadzie naszej ery na podstawie przekazów greckich spisał obszerne dzieło historyczne Historiae Philippicae, z którego zachował się tylko łaciński wyciąg. Natomiast w II-III wieku n.e. zapisał go historyk Junianus Justynus (Historiarum Philippicarum libri XLIV). Przywołana została tu postać króla Gargorisa, który nie chciał, by następcą tronu został Habis, nieślubny syn jego córki, dlatego też usiłował go zabić. Opowieść zgadza się ze wspomnianymi buddyjskimi narracjami, co uwypukla się w powtarzających się motywach intryg i sprzyjającego losu: król pozostawia noworodka w lesie, ale zwierzęta karmią dziecko i zostaje ono uratowane; następnie władca porzuca dziecko na drodze, żeby przechodzące bydło zadeptało je, ale zwierzęta nie robią mu żadnej krzywdy; w końcu król rzuca niemowlę wygłodniałym psom i świniom, ale nawet $\mathrm{z}$ tego podstępu dziecko wychodzi cało. $Z$ tych analogii Tille wnioskuje, że treść ta ma swoje korzenie w starożytnej Grecji, skąd następnie przedostała się na wschód, południe i zachód (Tille 1919: 76).

Oczywiste jest to, że tematyczny algorytm "protegowany losu” koresponduje z wieloma tzw. królewskimi opowieściami, na przykład o Cyrusie czy Romulusie i Remusie ${ }^{8}$. Do nich należą także europejskie średniowieczne, pseudohistoryczne

7 Opowieść o Ghósace wchodzi w skład buddyjskich zasad moralnych Dhammapada.

8 Romulus i Remus byli braćmi bliźniakami, ich matką była Rea Sylwia, córka króla Numitora, który został pozbawiony tronu przez stryja Amuliusa, z kolei brata Numitora zamordowano podczas polowania. Amulius wtrącił Numitora do więzienia, a jego córce Rei kazał zostać westalką i żyć w celibacie. Rea zaszła jednak w ciążę, urodziła dwóch chłopców. Ich ojcem był prawdopodobnie bóg wojny - Mars. Jako że westalkom zakazane były stosunki seksualne, Amulius dowiedziawszy się, że Rea urodziła dzieci, skazał ją na okrutną śmierć - wrzucił ją do Tybru (według innej legendy - zakopał ją żywcem). Amulius nakazał również słudze, żeby utopił synów Rei. Ten jednak wrzucił dzieci w koszyku do wód Tybru. Koszyk popłynął z prądem, ale zatrzymał się na mieliźnie w jednej z zatoczek, w miejscu przyszłego miasta - Rzym. Chłopców wykarmiła własnym mlekiem 
PORÓWNANIA NR 1 (22), 2018

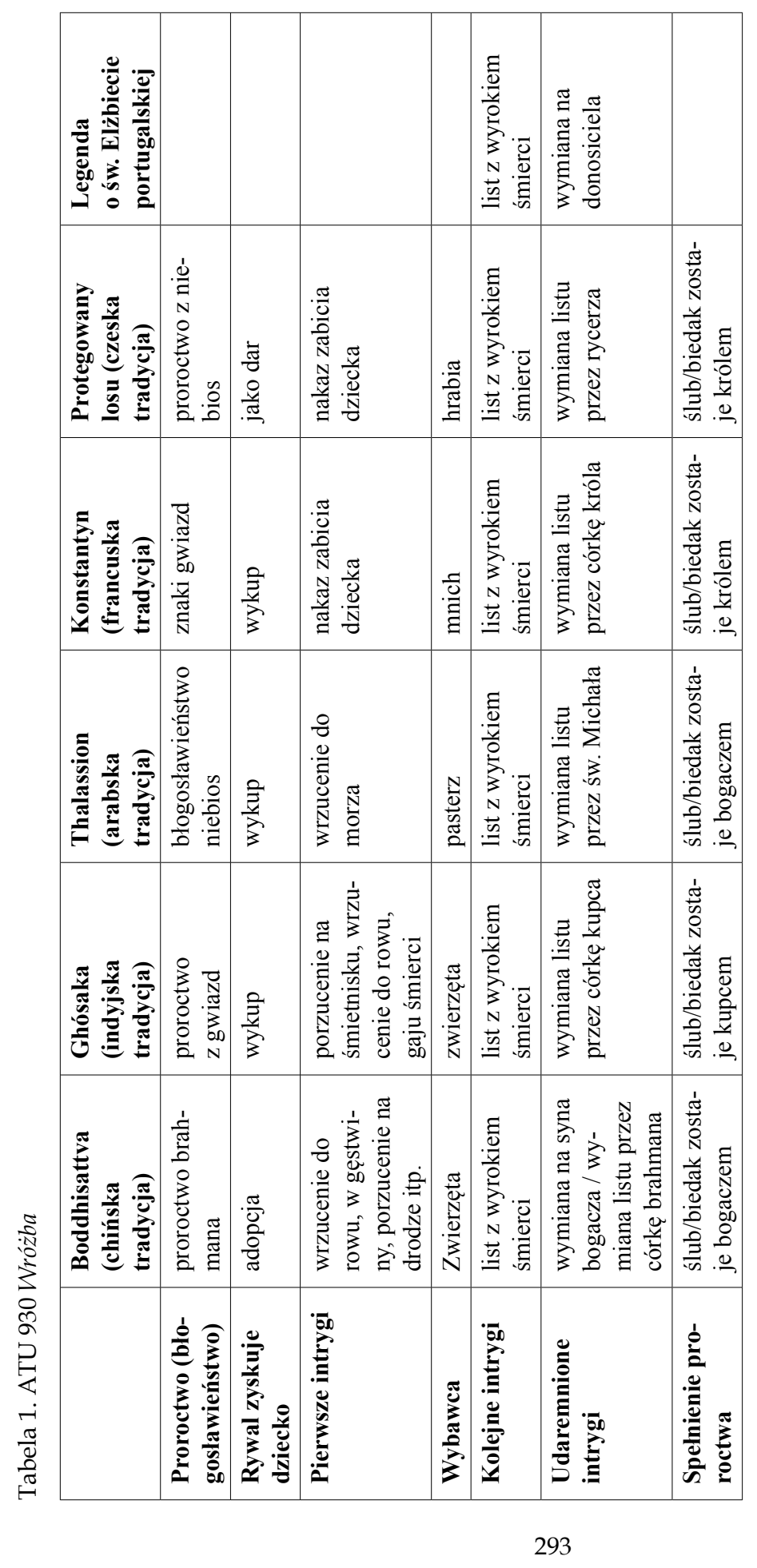


opowieści o bizantyjskim cesarzu Konstantynie (XIII wiek), o synu leśnika, którego prześladuje cesarz Hanibal (staroczeskie Gesta Romanorum, XIV-XV wiek) czy XVI-wieczna opowieść o hiszpańskim królu Florindzie.

W chrześcijańskich legendach z Egiptu i Abisynii (w arabskim rękopisie Thalassion, etiopskich Talasôn czy Bahran) owa "przychylność losu” zostaje spersonifikowana - przybiera postać Michała Archanioła. Legendy te zawierają, w porównaniu ze wspomnianym tekstem indyjskim, motyw wrzucania noworodka do morza i jego cudownego ocalenia (najczęstszy jest wątek, gdy fale morskie delikatnie wyrzucają dziecko na brzeg).

Jak się zatem okazuje, baśniowy typ ATU 930 Wróżba czerpie z symboli, motywów i algorytmów tematycznych "cyzelowanych” od wieków przez różne kultury. Wymienione paralele i spójne motywy opowieści „protegowanego losu” zostały przedstawione $\mathrm{w}$ tabeli 1 .

\section{Typ baśniowy Trzy włosy z czarciej brody}

O ile w orientalnych narracjach typu "protegowany losu” pojawiająca się sekwencja "posłania do hut” (zamiast niewinnego głównego bohatera umiera, pomimo wszelkich podstępów, inna postać, która zawsze jest jakoś powiązana z „pomysłodawcą" intryg) jest względnie częsta, o tyle w europejskich opowiadaniach ludowych typu "protegowany losu” charakterystyczna jest substytucja tejże sekwencji poprzez segmenty fabularne, w których bohater dostaje polecenie udania się do jakiejś demonicznej, ewentualnie innej nadprzyrodzonej istoty, na przykład po jej trzy włosy, sierść czy pióra.

Spróbujmy przybliżyć wątki tematyczne baśniowego typu ATU 461 Trzy włosy z czarciej brody:

I. Wstęp: a) proroctwo, według którego chłopiec zostanie zięciem króla; b) daremne próby zakłócenia jego ślubu z królewną;

II. Poszukiwanie czarcich włosów: bohater zostaje wysłany do piekła a) by przynieść trzy włosy z czarciej brody albo b) by przekonał się, kto jest najsilniejszym - najsprawniejszym człowiekiem na świecie.

III. Pytania (stawiane chłopcu podczas drogi): a) dlaczego drzewo, wokół którego wędruje, nie kwitnie; b) kiedy przewoźnik, który ma przeprawić chłopca na drugą stronę rzeki, będzie zwolniony ze swoich obowiązków; c) w jaki sposób można uzdrowić chorego księcia (księżniczkę); d) dlaczego wysechł strumień;

wilczyca, a po jakimś czasie koszyk z niemowlętami znalazł pasterz królewski Faustulus, wziął je i wraz z żoną Accą Laurentią zaopiekował się nimi. Gdy Romulus i Remus osiągnęli pełnoletniość i dowiedzieli się o swoim pochodzeniu, postanowili zabić króla Amuliusa, tym samym przywracając na tron prawowitego władcę Numitora. 
e) gdzie znajduje się zagubiona księżniczka; f) gdzie jest zgubiony klucz; g) jak może wyjść za mąż dziewczyna, której unikają adoratorzy; h) dlaczego żywi umierają.

IV. Powodzenie w szukaniu: a) chłopcu pomoże czarcia matka; b) chłopiec przemieni się w mrówkę i ukryje się w spódnicy czarciej matki; c) czart po przybyciu do swojej matki wyczuwa obecność człowieka, ale nie udaje mu się znaleźć chłopca; d) chłopiec dzięki pomocy czarciej matki uzyskuje odpowiedzi na postawione mu pytania: d1) pod drzewem ukryte jest złoto (albo wąż), które trzeba znaleźć, d2) przewoźnik musi oddać wiosło innej osobie, a ta przejmuje jego obowiązki, d3) księżniczka może zostać wyleczona tylko przez to, że odda święconą wodę, którą ukradła w kościele, d4) źródło zacznie ciec na nowo, jeśli zostanie z niego usunięte jakieś zwierzę albo kamień; e) chłopcu uda się uzyskać trzy włosy z czarciej brody (ewentualnie jego trzy złote włosy).

V. Nagrody: chłopiec podczas drogi do domu udziela odpowiedzi na zadane mu pytania i otrzymuje nagrodę (złoto, klejnoty, zwierzęta).

VI. Król zostaje przewoźnikiem: a) zazdrosny król usiłuje naśladować bohaterskie czyny młodzieńca; b) przewoźnik wręczy mu wiosła i król zostanie przewoźnikiem.

Jak widzimy, baśniowy typ ATU 461 jest rozszerzoną narracją typu ATU 930. Ekspozycję opowieści stanowi historia o „protegowanym losu” (ATU 930). W kolejnych częściach bohater wyrusza na wędrówkę do nieznanej krainy do - mrocznej lub niebiańskiej - istoty (oprócz diabła, czarta może to być także spersonifikowane słońce o imieniu Vratko, dziad Vševed, smok, wielki ptak czy Sybilla) i zdobywa jej trzy złote włosy.

Wędrowanie do pozaziemskiej istoty (przekształconej w różnorodne, spersonifikowane postaci) pozwala bohaterowi odnaleźć odpowiedzi mające mu pomóc rozwiązać poważne problemy, z którymi od wieków boryka się świat (w opowiadaniu wyrażony on zostaje przy pomocy wielu różnych królestw). Na przykład w słowackiej bajce Plavč́k a Vratko, čo osúšajú slzy sveta (Pływak i Vratko, którzy wycierają łzy świata) ludzie ubolewają z powodu wyschniętej studni, uschniętego drzewa owocowego czy (w przypadku przewoźnika) męczących usług.

Nawiedzenie „innego świata”, uzyskanie złotych włosów, które mają „wytrzeć łzy świata", powodują, że życie bohatera nabiera królewskiego charakteru, a za jego pośrednictwem dochodzi do odnowy świata.

Przedstawmy selektywnie niektóre europejskie warianty typu baśniowego ATU 461:

- wariant niemiecki: Der Teufel mit den drei goldenen Federn (bracia Grimm, 1812),

- wariant słowacki: Cesta k slunci (Ján Francisci-Rimavský, 1845),

- wariant czeski: Tři zlaté perá (Božena Němcová, 1846), 
- wariant czeski (morawski): O chovanci královském (Beneš Metod Kulda, 1854),

- wariant rosyjski: Marko bogatyj a Vasilij bezsčastnyj (Alexander Nikolayevich Afanasjev, 1855),

- wariant słowacki: Cesta $k$ slunci a k měsíci (Božena Němcová, 1857),

- wariant niemiecki (lipski): Die Reise zur Sonne (Josef Wenzig, 1857),

- wariant słowacki: Tri perá z draka, alebo hl'adanie zlého a dobrého (August Horislav Škultéty, Pavol Dobšinský, 1858), zob. także: Zlatá podkova, zlaté pero, zlatý vlas,

- wariant czeski: Tri zlaté vlasy Deda Vševeda (Karel Jaromír Erben, 1860),

- wariant czeski: Vyslaný k slunci (Jakub Malý, 1876).

W tradycji słowackiej baśniowy typ ATU 461 (ewentualnie jego konstrukcja treściowa) zostaje zastąpiony przez podstawowy wariant $O$ chudobnom chlapcovi a o dedovi Vševiadovi (O ubogim chłopcu i o dziadku Wszewiedzie), który dzieli się na kolejne warianty ${ }^{9} \mathrm{~A}$ i B.

Warianty $\mathrm{A}^{10}$, składające się z grupy I - wyprawa ku słońcu i grupy II - wyprawa ku zamorskiemu smokowi (szatanowi), to:

- Kristus so sv. Petrom jako mentor (Codex revúcky C, 57-58; Polívka III, 6-8);

- Barcélly, čo slzy osúšal (Dobšinský; Polívka III, 8-11);

- Rozprávka o jednom chudobnom Jankovi (Polívka III, 11-18);

- Tri perá z draka (Zábavník prešovský, 15-17);

- Tri perá z draka ako hl'adanie zlého a dobrého (Škultéty. Dobšinský, 125-135);

- Plavčík a Vratko, čo osúšajú slzy sveta (Dobšinský; Polívka III, 19).

Warianty $\mathrm{B}^{11}$ to:

- Plavčik: O troch perách z nochtivtáka.

W tym miejscu należy podkreślić, że oznaczenie typu ATU 461 o nazwie „protegowany losu", którego używają w swoich pracach Polívka i Tille, obejmuje jedynie pierwszą część opowieści (reprezentowaną przez typ ATU 930), nie rejestruje wszystkich podstawowych oznaczeń. Oznaczenie w międzynarodowym katalogu

9 Zob. Gašparíková. Podkreślić należy fakt, że Gašparíková jako ludowa komparatystka ma znaczne zasługi w obszarze studium porównawczego słowackiej ludowej prozy i w systematycznym opisie wielu tekstów na podstawie międzynarodowego katalogu Aarne i Thompsona (Aarne, Thompson). Gašparíková opracowała cały materiał, który opisał Polívka w pracy Súpis slovenských rozprávok I V. (1923-1931), zwłaszcza szeroki wybór tekstów z rozległego kolekcjonerskiego przedsięwzięcia, które udało się przeprowadzić prof. Frankowi Wollmanowi w latach 1928-1947 przy udziale swoich studentów.

10 Warianty A przedstawiają podstawowe warianty treści opowiadania, które zazwyczaj są zarejestrowane w Súpise slovenských rozprávok Polívky.

11 Warianty B obrazują paralele do podstawowych wariantów A. 
(Trzy włosy z czarciej brody) odpowiada z kolei tylko drugiej części opowieści tego typu, która, co więcej, pojawia się wyłącznie w jednej wersji. Dlatego też badacze sporządzający słowacki katalog typów baśni przy oznaczaniu typu ATU 461 i tworzeniu sumarycznego katalogu treści dali pierwszeństwo starszej, łączonej nazwie, którą wykorzystywał Tille a mianowicie: Protegowany losu i wyprawa po trzy złote włosy $(k u \text { słońcu })^{12}$.

Na płaszczyźnie typologicznej zarejestrować można więcej wzorów opowieści typu ATU 461. Gašparíková drugą część wątku z typu ATU 461 („wędrówka do nadprzyrodzonej istoty") uważała za „sekundarny twór treści o drodze do Boga, od którego bohater ma otrzymać nagrodę albo odpowiedź na pytania" (Gašparíková 676). Motyw niebezpiecznej wyprawy do Boga, ewentualnie w rejony zaświatów ma niezwykle długą tradycję. Świadczyć o tym mogą poszczególne etapy drogi protegowanego, na przykład przeprawa przez morze do nieznanego świata czy wędrówka do władcy owego świata. Jedną z najstarszych narracji o wyprawie $\mathrm{w}$ zaświaty jest asyryjska opowieść o Izdubarze (prawdopodobnie powstała $\mathrm{w}$ trzecim tysiącleciu p.n.e.), której fragmenty zachowały się na asyryjskich tabliczkach z VI wieku p.n.e. (Jeremias 14-44): Izdubar zachorował i wybrał się do świata umarłych, żeby odnaleźć swojego praojca - to miało mu pomóc w uzdrowieniu i dowiedzeniu się czegoś o własnej przeszłości. Wyruszył w góry, których strzegły dwa olbrzymie skorpiony - ich zadaniem było pilnowanie, żeby nikogo dalej nie przepuścić. Skoro Izdubar był półbogiem, skorpiony pozwoliły mu przejść. Bohater musiał przemierzyć ciemności, żeby dotrzeć do brzegu morza, przy którym znajdował się pałac pięknej dziewczyny. Tam dowiedział się o zasadzkach czyhających na niego w kolejnych etapach wyprawy. Odnalazł przewoźnika, który przeprawił go do ziemi szczęśliwości, gdzie spotkał się ze swoim praojcem. Jego żona uśpiła Izdubara magicznym napojem, a przewoźnik doprowadził go do zdroju życia, który przywrócił mu zdrowie. Bohater powrócił do praojca, który wyjawił mu tajemnicę odmładzających i odżywczych ziół.

Inne literackie opracowania baśniowej treści typu ATU 461 nie są znane, jednakże istnieje sporo wariantów $\mathrm{w}$ tradycji ustnej $\mathrm{z}$ wielu europejskich i azjatyckich krajów (oraz sporadycznie z Ameryki Łacińskiej). Z niektórymi elementami tych treści, na przykład z prastarym motywem włosów jako symbolu, przejawu/wypowiedzi czy wprost źródła życiodajnej siły spotkać się można już u Ajschylosa (525 rok p.n.e.), Apollodorosa (II wiek), Owidiusza (zmarł w 17 roku n.e.) i innych (Gašparíková 676).

Na uwagę zasługuje też mit o Bellerofoncie z Iliady Homera ('spiew VI). Anateja, żona tirynskiego króla Projtosa, próbuje uwieść Bellerofonta, ale on nie odwzajemnia jej uczuć. Anateja chce się więc na nim zemścić, oskarżając go o zaloty. Król wysyła Bellerofonta z listem zawierającym wyrok śmierci do swojego teścia - króla

12 Zob.: Gašparíková 676-677. 
Licji Jobatesa. Ten jednak nie potrafi zabić Bellerofonta, więc kieruje go do niebezpiecznej Chimery, licząc na to, że tam spotka go śmierć. Bohater przy pomocy wróżbity Polyida zabija potwora, a na znak, że wykonał polecenie, przynosi go Jobatesowi. Zasadzki na jego życie nie powiodą się nawet podczas wypraw za dzikimi Solimerami czy Amazonkami. Bogowie pomogą mu udowodnić jego niewinność (uwaga: mit o Bellerofoncie nie obejmuje wstępnego motywu pierwszej części typu 461: zależnego od losu przeznaczenia małżeństwa ubogiego bohatera z zamożną dziewczyną, tym samym i motywu prób pozbycia się z tego powodu protegowanego przez jego rywala).

Tabela nr 2 pokazuje paralele motywów, ewentualnie zgodność narracji, które przedstawiają warianty albo analogie typu ATU 461.

Tabela 2. ATU 461 Trzy włosy z czarciej brody

\begin{tabular}{|c|c|c|c|c|c|}
\hline & $\begin{array}{l}\text { Mit } \\
\text { o Bellerofoncie }\end{array}$ & $\begin{array}{l}\text { Czarcie trzy } \\
\text { zlote wlosy } \\
\text { (niemiecka } \\
\text { tradycja) }\end{array}$ & $\begin{array}{l}\text { Dziad } \\
\text { V̌seved } \\
\text { (czeska } \\
\text { tradycja) }\end{array}$ & $\begin{array}{l}\text { Plavčík } \\
\text { a Vratko, } \\
\text { čo osúšajú } \\
\text { slzy sveta } \\
\text { (słowacka } \\
\text { tradycja) }\end{array}$ & $\begin{array}{l}\text { Chrystus ze } \\
\text { św. Piotrem } \\
\text { jako mentor } \\
\text { (słowacka } \\
\text { tradycja) }\end{array}$ \\
\hline Wróżba & & $\begin{array}{l}\text { boginie prze- } \\
\text { znaczenia - } \\
\text { ślub z córką } \\
\text { króla }\end{array}$ & $\begin{array}{l}\text { bogini prze- } \\
\text { znaczenia - } \\
\text { ślub z córką } \\
\text { króla }\end{array}$ & $\begin{array}{l}\text { kuma - ślub } \\
\text { z córką króla }\end{array}$ & $\begin{array}{l}\text { Chrystus - } \\
\text { ślub z córką } \\
\text { króla }\end{array}$ \\
\hline $\begin{array}{l}\text { Wyprawa do } \\
\text { niebezpiecznej } \\
\text { istoty }\end{array}$ & $\begin{array}{l}\text { do potwora } \\
\text { Chimery }\end{array}$ & do diabła & $\begin{array}{l}\text { do dziada } \\
\text { Vševeda }\end{array}$ & do Vratka & do smoka \\
\hline $\begin{array}{l}\text { Powodzenie/ } \\
\text { nagroda }\end{array}$ & zabicie potwora & $\begin{array}{l}\text { trzy zło- } \\
\text { te włosy, } \\
\text { odpowiedzi } \\
\text { na pytania, } \\
\text { bogactwo }\end{array}$ & $\begin{array}{l}\text { trzy zło- } \\
\text { te włosy, } \\
\text { odpowiedzi } \\
\text { na pytania, } \\
\text { bogactwo }\end{array}$ & $\begin{array}{l}\text { trzy złote } \\
\text { włosy, } \\
\text { odpowiedzi } \\
\text { na pytania, } \\
\text { bogactwo }\end{array}$ & $\begin{array}{l}\text { trzy zło- } \\
\text { te pióra, } \\
\text { odpowiedzi } \\
\text { na pytania, } \\
\text { bogactwo }\end{array}$ \\
\hline $\begin{array}{l}\text { Spelnienie } \\
\text { wróżby }\end{array}$ & & $\begin{array}{l}\text { król przewoź- } \\
\text { nikiem / bie- } \\
\text { dak królem }\end{array}$ & $\begin{array}{l}\text { król przewoź- } \\
\text { nikiem / bie- } \\
\text { dak królem }\end{array}$ & $\begin{array}{l}\text { biedak } \\
\text { królem }\end{array}$ & $\begin{array}{l}\text { król przewoź- } \\
\text { nikiem / bie- } \\
\text { dak królem }\end{array}$ \\
\hline
\end{tabular}

Zatrzymajmy się jeszcze przy kilku innych kluczowych motywach baśniowego typu 461.

\section{Prześladowanie niemowlęcia}

Podobny motyw z opowieści znaleźć można w biblijnej historii o królu Herodzie, którego nawiedzają trzej mędrcy ze Wschodu i któremu ogłaszają nowinę o narodzeniu się nowego króla. Herod wydaje rozkaz zabicia wszystkich noworod- 
ków - chłopców, żeby pozbyć się swojego rywala, jednakże los nowego króla jest zaplanowany przez Boga.

W prastarym indyjskim micie Kryszna prorok przepowiada królowi Kansowi, że umrze okrutną śmiercią, a zastąpi go ósmy syn jego siostry Dewaki, który miał się niebawem narodzić jako awatar boga Wisznu. Kansa rozkazuje zabić dzieci księżniczki, bogowie jednak interweniują i ósme dziecko - Kryszna - ocaleje („Nic nie może powstrzymać losu..."; Martínková 68-69). Kryszna żyje incognito u zastępczych rodziców w pasterskiej chacie, żeby wypełnić swoje boskie posłannictwo.

\section{Uratowanie chłopca}

Motyw ten ma swoją analogię w starotestamentowej opowieści o Mojżeszu, którego matka puściła w koszu na rzekę. Dziecko wyłowiła Termutis - córka faraona, natomiast siostra niemowlęcia, Miriam poradziła Termutis, by płaczące dziecko nakarmiła jakaś kobieta $\mathrm{z}$ plemienia. $\mathrm{W}$ ten sposób prawowitej matce powierzono nakarmienie i wychowanie jej własnego syna.

Motyw matki-karmicielki pojawia się także w słowackiej bajce autorstwa Boženy Němcovej Kristus so sv. Petrom jako mentor. Matka umieszcza swoje dziecko w łódce i puszcza je na wodę. To ma uratować je przed gniewem króla. Łódka przypływa do młyna, którym zarządza bezdzietne małżeństwo. Oni przygarniają niemowlę, zaś prawdziwa matka przychodzi ingocnito karmić dziecko.

\section{Motyw znaków z nieba}

W bajce Kristus so sv. Petrom jako mentor Chrystus pełni rolę proroka i ojca chrzestnego. Kiedy żona rolnika dostaje bólów porodowych, Chrystus posyła św. Piotra, żeby obserwował niebo i opóźniał poród, dopóki na niebie nie pojawią się pomyślne znaki. Chrystus prorokuje następnie, że chłopiec zostanie królem. Rano obaj Chrystus i św. Piotr - zostają kumami (prawdopodobnie mamy tu do czynienia z posttekstem, który nawiązuje do nowotestamentowej historii o trzech mędrcach ze Wschodu, którym gwiazda zwiastuje miejsce narodzenia Jezusa).

Analogiczny motyw pojawia się w starofrancuskim śpiewie $O$ cesarzu Konstantynie. Astrolog przy pomocy nadprzyrodzonej siły planuje poród swojej żony według pojawiających się znaków na niebie. Po porodzie zwierza się przyjacielowi, że nowonarodzony syn ma zostać królem. Rozmowę tę podsłuchuje król Floriens i nakazuje zabić chłopca.

Mitologiczny motyw "dziecka bożego", którego los dyktują istoty niebiańskie, wykracza poza paradygmat motywów typu ATU 461. Dziecko takie posiada rodziców: a) ziemskich, biologicznych i przybranych (młynarz, drwal, rolnik, kupiec itd.) i b) boskich (wcielonych w postać rodziców chrzestnych, bogini przeznaczenia, Chrystusa etc.). Tym samym dziecko należy niejako do dwóch światów - ludzkiego i boskiego. Jego posłannictwem jest wniesienie „boskiego pierwiastka” do ziemskiej egzystencji i jej zasadnicza zmiana. 


\section{Spełnienie przepowiedni/proroctwa}

Proroctwo wskazuje, że los, który protegowanemu wyznaczyli „ci z innego świata", zakończy się powodzeniem nawet mimo woli „ludzi z tego świata”. Paradoksalnie, to właśnie opór ziemskich nieprzyjaciół umożliwi wypełnienie tego, co wybrańcowi jest dane $\mathrm{z}$ nieba.

Podsumowując, można pokusić się o stwierdzenie, że niezmiennym semantemem obu baśniowych typów (ATU 930 Wróżba i ATU 461 Trzy włosy z czarciej brody) jest dążenie wysoko postawionego, posiadającego władzę mężczyzny do zabicia tego, który według przepowiedni czy wróżby ma stać się jego następcą.

Istnieją liczne wskazówki (mimo że wiele $\mathrm{z}$ nich jest jedynie hipotetycznych), że obie części typu ATU 461 mają starożytne pochodzenie. Według Gašparíkowej pierwsza część (ekspozycja opowieści „protegowanego losu”) z wielkim prawdopodobieństwem pochodzi z okresu homerycko-mykeńskiego, ewentualnie z okresu przed 700 rokiem n.e. $W$ helleńsko-rzymskim okresie natomiast (300 rok p.n.e. - 300 rok n.e.) niektóre jej warianty przyjęły cechy legend. Prawdopodobnie obie części połączyły się w zaawansowanym okresie bizantyjsko-chrześcijańskim (Gašparíková 676).

Mamy tym samym do czynienia z arcynarracją, która wędruje od wieków przez wiele kontynentów (Azja, Afryka, Europa) z jednej strony jako wyraz, jak to określił Tille, „głęboko tragicznego poglądu na życie: jak próżny jest ludzki wysiłek sprzeciwiania się woli tajemniczego odwiecznego niewiadomego" (Tille 1918: 369), z drugiej natomiast jako wyraz nieustannego ludzkiego pragnienia, żeby spoić sposób i sens własnej egzystencji z ponadziemskim błogosławieństwem.

\section{Tłumaczenie z języka słowackiego: Małgorzata Dambek}

\section{BIBLIOGRAFIA}

Aarne, Antti. Der reiche Mann und sein Schwiegersohn. Hamina: FFC, 1916.

Aarne Antti, Thompson Stith. The Types of the Folktale. Helsinky: FFC, 1961.

Afanasjev, Alexandr Nikolajevič. Narodnye russkie skazki 2. Moskva: A. Semen, 1855.

Bolte Johannes, Polívka Georg. Anmerkungen zu den Kinder- und Hausmärchen der Brüder Grimm. Leipzig:

Dieterische Verlagsbuchhandlung Theodor Weicher, 1913.

Brüder Grimm. Kinder- und Hausmärchen. Band 1. Berlin: Realschulbuchhandlung, 1812.

Codex revúcky C, 1843-1844.

Cosquin, Emmanuel. La Légende du page desainte Elisabeth de Portugalet les nouveaux documents orientaux.

Paris: Auxbureauxde la Revue, 1912.

Dobšinský, Pavol. Prostonárodnie slovenské povesti. Zošit 8. Turčiansky sv. Martin, 1883.

Dobšinský, Pavol. Slovenské národné povesti. Bratislava: Nestor, 1996.

Erben, Karel Jaromír. Máj. „Máj“, č. 4. Praha 1860. 
Francisci-Rimavský, Ján. Slovenskje povestí. Levoča: Jan Werthmüller a sin, 1845.

Gašparíková Viera, red. Slovenské l’udové rozprávky. T. 1. Bratislava: Veda, 2002.

Homéros. Ilias. Bratislava: Slovenský spisovatel', 1986.

Horálek, Karel. Folklór a světová literatura. Praha: Academia, 1979.

Jeremias, Alfred. Izdubar - Nimrod. Eine Altbabylonische Heldensage. Leipzig: B. G. Teubner, 1891.

Kadečková, Helena. Př́běh Amleta, prince jutského, jak jej ve své dánské kronice napsal Saxo Grammaticus. Praha: LEDA, 1996.

Kulda, Beneš Metod. Moravské národní pohádky a pověsti z okoli Rožnovského. Brno: Tiskem dědicův R. Rohrera, 1854.

Malý, Jakub Budislav. Báchorky a pověsti národní IV. Praha: Kober, 1876.

Martínková Jana, O zlatém vejci, Brahmovi a vesmírnych světech. Mýty starých Indů. Praha: Argo, 2010.

Němcová, Božena. Národní báchorky a pověsti. Praha: Tisk a sklad Jaroslava Pospíšila, 1846.

Němcová, Božena. Slovenské pohádky a pověsti II. Praha: Nákladem kněhkupectví Josefa Šálka, 1857.

Polívka, Jiří. Súpis slovenských rozprávok I - V. Turčiansky Sv. Martin: Kníhtlačiarsky účastinársky spolok, 1923-1931.

Schick, Joseph. Corpus Hamleticum. Berlin: Felber, 1912.

Škultéty August Horislav, Dobšinský Pavol. Slovenské povesti. Kniha prvá. Sväzok III. Banská Štiavnica: tlačom Františka Lorbera, 1859.

Tille, Václav. "Chráněnec osudu". Národopisný věstník českoslovanský XII. Praha, 1918. S. 369-417.

Tille, Václav. Doplňky. “Chráněnec osudu”. Národopisný věstník českoslovanský XIII. Praha, 1919. S. 76-78.

Wenzig, Josef. Westslawischer Märchenschatz. Leipzig: C. B. Lorck, 1857. 
